\title{
DEFECTIVENESS OF EXTERNAL AND INTERNAL SURFACES OF THE MAIN OIL AND GAS PIPELINES AFTER LONG-TERM OPERATION
}

\author{
Pavlo MARUSCHAK ${ }^{\mathrm{a}}$, Olegas PRENTKOVSKIS ${ }^{\mathrm{b}}$, Roman BISHCHAK ${ }^{\mathrm{c}}$ \\ aDepartment of Industrial Automation, Ternopil National Ivan Pul'uj Technical University, \\ Rus'ka str. 56, 46001 Ternopil, Ukraine \\ ${ }^{b}$ Department of Transport Technological Equipment, Vilnius Gediminas Technical University, \\ Plytinés g. 27, LT-10105 Vilnius, Lithuania \\ ${ }^{c}$ Department of Welding of Main Pipelines, Ivano-Frankivsk National Technical University of Oil and Gas, \\ Karpatska str. 15, 76000 Ivano-Frankivsk, Ukraine
}

Received 23 Feb 2015; accepted 08 Aug 2015

\begin{abstract}
Damage by pitting corrosion of the surface areas of the local oil and gas pipelines was identified and numerically analysed in this paper. Having used the methods of optical and scanning electron microscopy, the basic laws of structural and mechanical degradation were established. Based on the data of fractographic control, the shape of defects and substantiated morphological characteristics were examined. It was established that certain informative signs of the defects correspond to certain stages of operation. Having used methods of fractodiagnostics, the main reasons for the performance defects of main oil and gas pipelines were established, and the mechanisms of degradation as well as fracture of the materials they are made from were described. According to the findings, the cause of the decrease in the reliability of the main oil and gas pipeline networks is general and localised corrosion as well as technological defects in the pipeline metal. These studies are essential for the establishment of the complex of mechanical and corrosion-mechanical properties, particularly sensitive to degradation in the steel used for the pipe wall after a lengthy use of a pipe.
\end{abstract}

Keywords: fracture, failure, structural damage, strain localisation, hydrogenation, degradation, gas pipeline.

\section{Introduction}

Several main gas pipelines run through the territory of Ukraine transporting gas to Europe (Voropai et al. 2012), Figure 1:

- "Soyuz" (length - $1567.3 \mathrm{~km}$ );

- "Urengoy-Pomary-Uzhgorod", also known as the "Trans-Siberian Pipeline" (length - 1160 km);

- "Progress" (length - 1127.3 km).

JSC "UkrTransNafta" operates the main oil pipelines "Druzhba", the system of which is used for the oil transportation from Russia to Europe. This system consists of the following oil pipelines (Fig. 1):

- "Mozyr-Brody" (length - 365 km);

- "Brody-State Border" (length - $325 \mathrm{~km}$ );

- "Odessa-Brody" (length - 674 km);

- "Dolyna-Drohobych";

- "Zhulin-Nadvirna".

The analysis of the operating conditions of the main oil and gas pipelines has proved conclusively that the defects of metallurgical origin are one of the reasons for the formation of the corrosion damage and a decrease in their working capacity. The existing systems of electrochemical protection are not always effective at protecting the main gas pipelines from corrosion. One of the main reasons for that is the influence of physical and mechanical properties of soils (Nykyforchyn et al. 2009a, 2010).

Most of the main oil and gas pipelines located on the territory of Ukraine are made of the low-alloy pipe steel. They have a protective film coating applied by the trace deposition, whose pre-set service life has already expired.

The reliability of the main pipeline systems depends largely on the condition of the anti-corrosion protection, in particular, the insulating coating. The insulation material ages, breaks down and exfoliates under the influence of the soil ground, losing its protective properties (Chernov et al. 2002a). Such areas are the potential sections of nucleation of the localised corrosion pits in the vicinity of the structural non-uniformities or metallurgical defects. The existing approaches to the complex technical diagnostics and the analysis of the safe operation of pipelines, reservoirs and high-pressure vessels consider these peculiarities only partly (Chernov et al. 2002b; Konovalenko et al. 2014; Tsyrul'nyk et al. 2007). Therefore, it is necessary to create a strength technique supporting a troublefree operation of gas and oil pipelines, which would be based on the time-tested ultimate state assessment cri-

Corresponding author: Pavlo Maruschak

E-mail: maruschak.tu.edu@gmail.com 


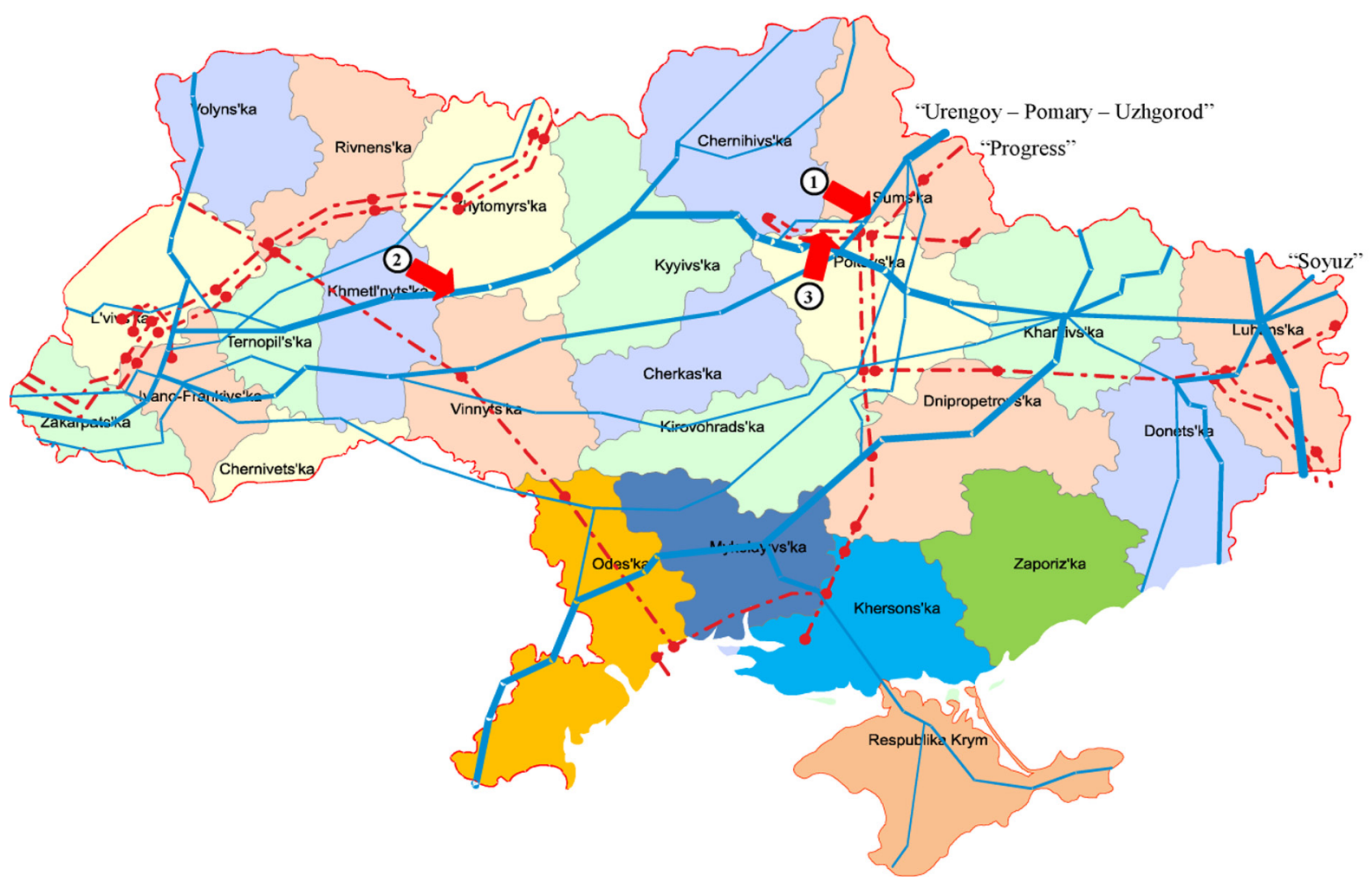

Fig. 1. Scheme of the Ukrainian main gas and oil pipelines (Voropai et al. 2012) and the steel billets of the investigated pipelines in the taking places (arrow marked): 1 - pipe branch "Mekhedivsko-Golotovshchinska Temporary Metering and Separation Station (TMSS)" of the main gas pipeline "Kursk-Kyiv"; 2 - main gas pipeline "Kyiv-West of Ukraine-1"; 3 - oil pipeline "Gnidyntsi-Glynsko-Rozbyshivska"

teria, prediction of the brittle, mixed (quasi-brittle) and ductile failure, taking into account the results of fractodiagnostics. Due to the variety of forms and the graded nature of manifestations of the general and localised corrosion, the ongoing monitoring of the oil and gas sector units is complicated significantly (Maruschak et al. 2014b; Slobodyan et al. 2002).

Based on the presented set of experimental results (Maruschak et al. 2013, 2014b, 2014c, 2015, 2016a, 2016b; Slobodyan et al. 2002; Nykyforchyn et al. 2009a; Chernov et al. 2002a, 2002b; Yemelin 2011; Liu et al. 2014; Konovalenko et al. 2014; Tsyrul'nyk et al. 2007; Chausov et al. 2015; Okipnyi et al. 2015), a conclusion can be made about the need for considering the effect of hydrogen on the degradation processes in the gas pipeline steel during its long-term operation. A source of metal hydrogenation in the pipe wall can be the corrosion processes occurring on its external surface, which are con- nected with the participation of hydrocarbon ions in the cathodic reaction.

Thus, an in-depth study of the regularities in the degradation of pipe steels, considering the structural nonuniformity of the material, its evolution, and the effect of the in-service factors on the nucleation and propagation of damage of the main pipeline systems with a view to giving a more precise definition to the methods of their prediction, remains topical.

The purpose of this work is to establish the main regularities in the propagation of defects of the external and internal surfaces of the main oil and gas pipelines after a long-term operation.

\section{Research technique}

Fragments of the main gas pipeline, a pipe branch and an oil pipeline after a long-term operation were investigated. All the objects under study had defects of various nature (Table 1).

Table 1. Parameters of investigated sections of gas and oil pipelines (Ukraine)

\begin{tabular}{|c|c|c|c|c|c|}
\hline Pipeline type and name & Defect & $\begin{array}{c}D, \\
\mathrm{~mm}\end{array}$ & $\begin{array}{c}h, \\
\mathrm{~mm}\end{array}$ & $\begin{array}{c}P \\
\mathrm{MPa}\end{array}$ & Years in service \\
\hline $\begin{array}{l}\text { Pipe branch "Mekhedivsko-Golotovshchinska } \\
\text { Temporary Metering and Separation Station } \\
\text { (TMSS)" of the main gas pipeline "Kursk-Kyiv" }\end{array}$ & $\begin{array}{l}\text { Megalospheric } \\
\text { hollows }\end{array}$ & 325 & 8.0 & $>5.5$ & 9.0 \\
\hline Oil pipeline "Gnidyntsi-Glynsko-Rozbyshivska" & Films & 377 & 9.0 & - & 50.0 \\
\hline Main gas pipeline "Kyiv-West of Ukraine-1" & Micro pitting & 1020 & 10.0 & 12.0 & 40 \\
\hline
\end{tabular}


A fragment of the main gas pipeline "Kyiv-West of Ukraine-1", with the diameter of $1020 \mathrm{~mm}$, wall thickness of $10 \mathrm{~mm}$ and the rubber-bitumen insulation coating was investigated. The corrosion damage in the form of stains, pits and caverns of different size and shape appeared due to failure of insulation on the external surface of the pipeline resulting from the interaction of the pipe metal with the environment.

We analysed a template cut out of a pipe branch of the main gas pipeline "Kursk-Kyiv" with the diameter of $325 \mathrm{~mm}$, wall thickness of $8 \mathrm{~mm}$, and the enhanced bitumen insulation after 9 years of operation. The pipeline was operated under the operating pressure up to $5.5 \mathrm{MPa}$. The pipeline section under investigation ran through a boggy ravine with sloping sides of $1.5-2 \mathrm{~m}$ in depth. Considering the relief of the area, through which the gas pipeline runs, the accumulation of liquid (water condensate and gas condensate) in the lower part of the pipeline could be presumed.

A fragment of the oil pipeline "Gnidyntsi-GlynskoRozbyshivska" with the diameter of $377 \mathrm{~mm}$ and the wall thickness of $9 \mathrm{~mm}$ was considered. The oil pipeline material was steel 20 after 50 years of operation.

After investigation of the pipes in the radial and axial directions, fragments were cut on the specialised machine Q-80Z (URMO-80A) with water-cooling.

\section{Damage and failure analysis and discussion}

\section{Main gas pipeline "Kyiv-West of Ukraine-1",}

length $-367 \mathrm{~km}$

Black inclusions in the form of corrosion pits were found on the surface of the gas pipeline fragment (Fig. 2a, b). It should be noted that some characteristic sections, within which the corrosion damage of the metal occurred, could be seen on the metal surface.

Based on the analysis of the gas pipeline surface, a number of conclusions can be made:

- surface damage has either a circular structure or a complex profile (Konovalenko et al. 2014; Maruschak et al. 2014d);

- the shape of pitting changes due to its individual growth or coalescence of pitting.

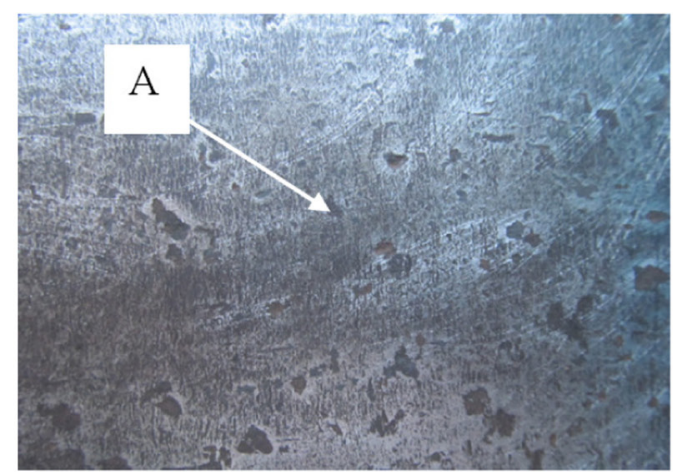

a)

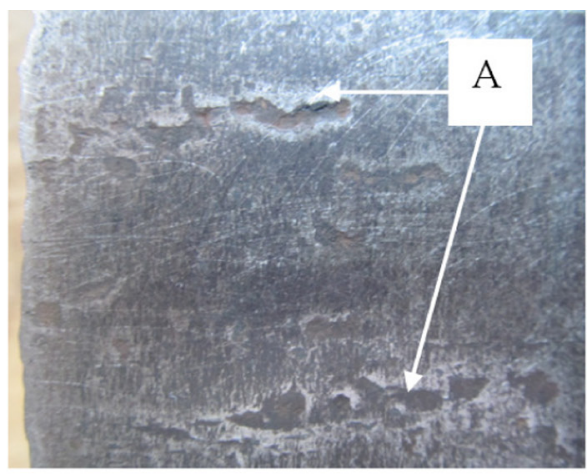

b)

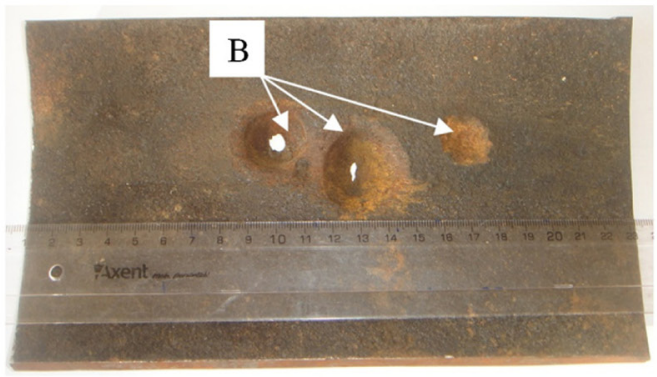

c)

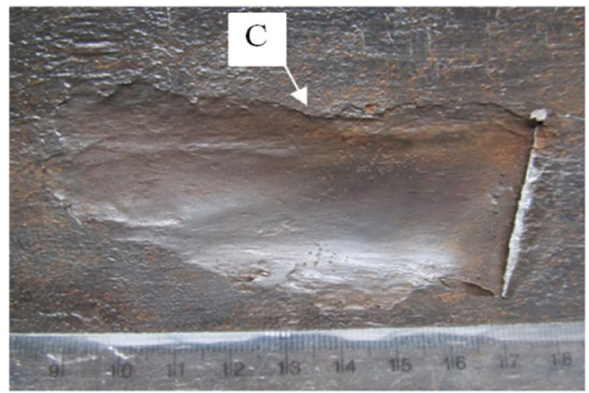

d)

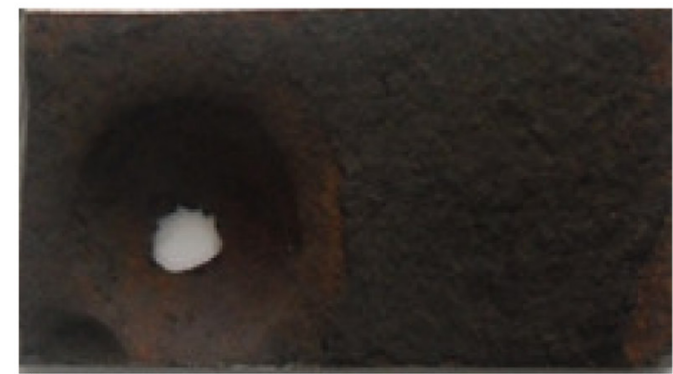

e)

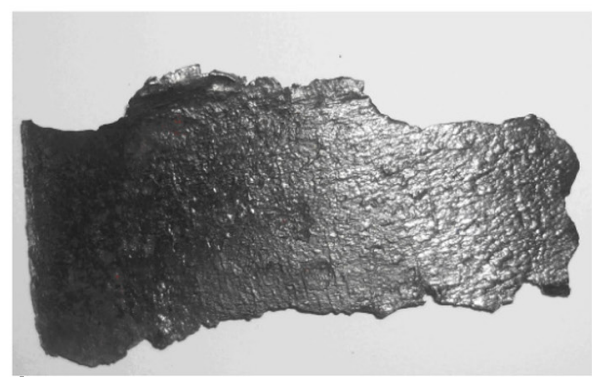

f)

Fig. 2. Investigated in-service defects of oil and gas pipelines: $a, b$ - pitting; $d, f$ - film peeling; $\mathrm{c}, \mathrm{e}-$ megalospheric corrosion pits; A, B, C - defects are indicated by arrows 
Table 2. Chemical composition of a pipe of the main gas pipeline "Kyiv-West of Ukraine-1" (Steel 17G1S)

\begin{tabular}{cccccccccccc}
\hline $\mathrm{Fe}$ & $\mathrm{C}$ & $\mathrm{Si}$ & $\mathrm{Mn}$ & $\mathrm{Cr}$ & $\mathrm{Mo}$ & $\mathrm{Ni}$ & $\mathrm{Al}$ & $\mathrm{Cu}$ & $\mathrm{Nb}$ & $\mathrm{Ti}$ & $\mathrm{Cu}$ \\
\hline 97.3 & 0.169 & 0.538 & 1.55 & 0.286 & 0.002 & 0.0355 & 0.0126 & 0.0419 & 0.0154 & 0.0161 & 0.25 \\
\hline
\end{tabular}

Table 3. Chemical composition of a pipe of the gas pipeline Mekhedivsko-Golotovshchinska TMSS (Steel 20G2)

\begin{tabular}{ccccccccccc}
\hline $\mathrm{Fe}$ & $\mathrm{C}$ & $\mathrm{Si}$ & $\mathrm{Mn}$ & $\mathrm{Cr}$ & $\mathrm{Mo}$ & $\mathrm{Ni}$ & $\mathrm{Al}$ & $\mathrm{Cu}$ & $\mathrm{Nb}$ & $\mathrm{W}$ \\
\hline 97.5 & 0.225 & 0.56 & 1.48 & 0.008 & 0.002 & 0.036 & 0.051 & 0.096 & 0.014 & 0.02 \\
\hline
\end{tabular}

Using the methods of the optical or scanning electron microscopy, it was established that the fracture surface is covered with a dense network of deep, largesized $(200-500 \mu \mathrm{m})$ pits, which were the result of the corrosion effect during operation.

The chemical composition of the fragment of the main gas pipeline was determined using the portative optical emission analyser PMI-master UVR. The results are presented in Table 2.

The shape of individual corrosion pits is uneven, which can be explained by the non-uniform fibrous structure and a high anisotropy of the pipe steel properties, which increases due to degradation, causing nonuniform localisation of the corrosion process (Maruschak et al. 2014a; Aleksandrov et al. 2011).

The presence of the pitting corrosion (Fig. 3a) intensifies degradation processes due to:

- the formation of the atomic hydrogen on the pipe surface in case of penetration of the ground water into the pipe surface (Nykyforchyn et al. 2009b);

- metal decarbonisation resulting from blockage of carbon atoms by the diffusion hydrogen atoms;

- metal hydrogenation and accumulation in dislocations, structural defects and micropores;

- metal embrittlement.
Thus, for the investigated sections of the main pipelines, the danger it is not in multiple pitting (Figs 3b-d) but the activation of the structural and mechanical degradation caused by them.

\section{Pipe branch "Mekhedivsko-Golotovshchinska TMSS"}

Defects in the form of through holes in the pipeline wall were investigated (Fig. 2c, e). Fragments with through holes were cut from the damaged section to determine the reason for their formation. The results of determining the chemical composition of the gas pipeline fragment are presented in Table 3.

According to the optical macroanalysis of the internal and external surfaces of the pipe in the initial state and after deseaming, holes have a semispherical shape. The semi-sphere diameter on the internal surface of the pipe is $22 \mathrm{~mm}$. A hole with the diameter of $6 \mathrm{~mm}$ appeared on the external wall, the metal thickness in the vicinity of the hole is less than $0.5 \mathrm{~mm}$ (Fig. 4a). The internal surface of the defect is covered with a thick layer of oxides. The oxides have sections of local bulging, in which a layer of corrosion separated easily from the lower corrosion layer. This testifies to the fact that corrosion developed gradually, in a stepwise manner within this section. There are traces of the uniform corrosion and

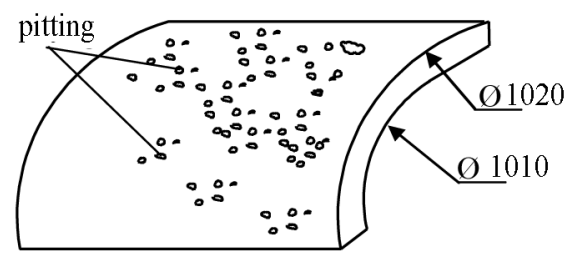

a)

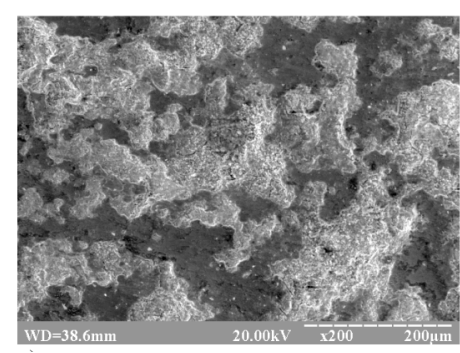

c)

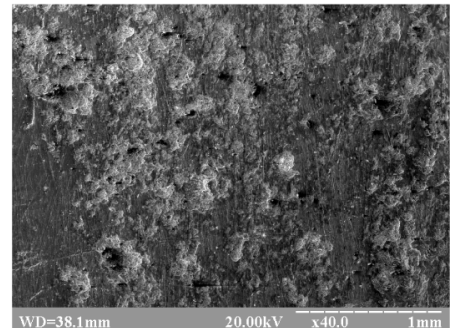

b)

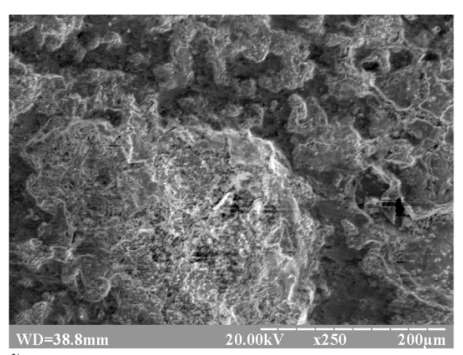

d)

Fig. 3. Scheme of multiple pitting location on the pipe surface (a); local (b) and coalesced pitting $(\mathrm{c}, \mathrm{d})$ 


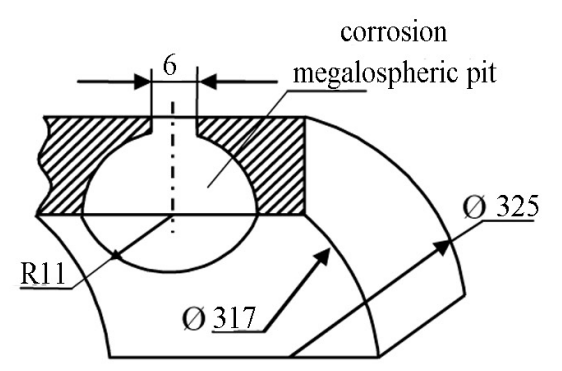

a)

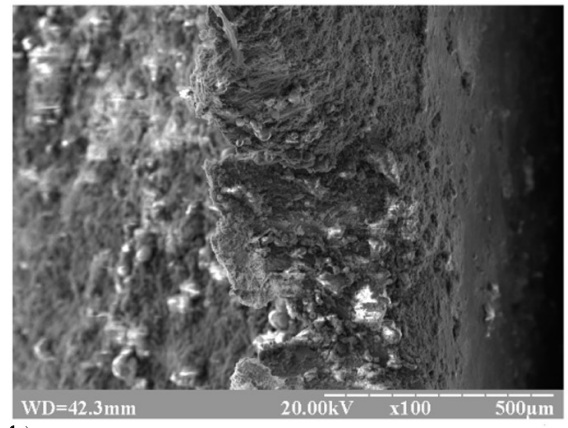

b)

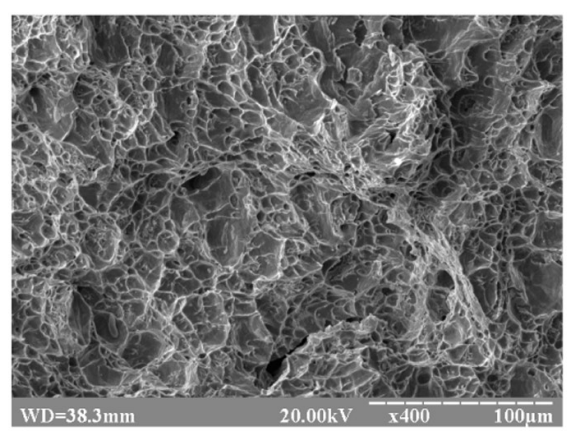

d)

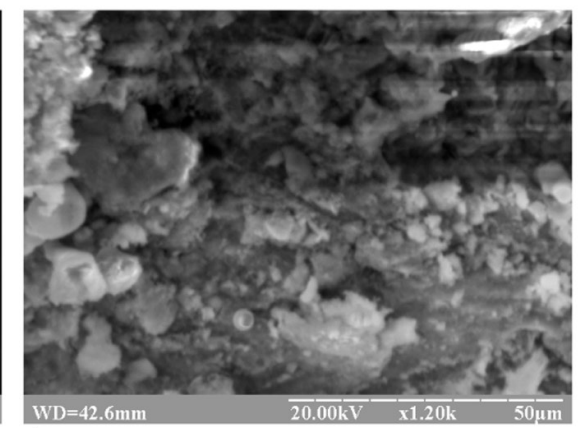

c)

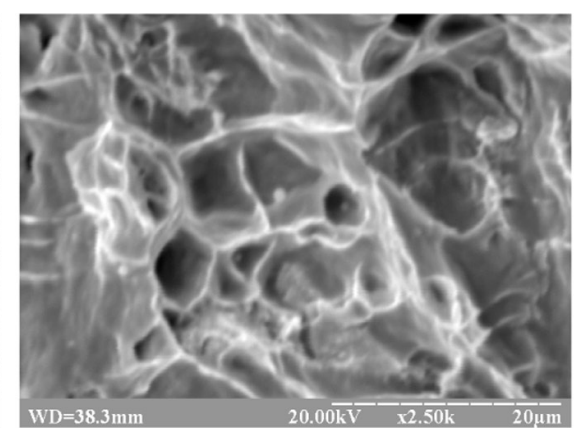

e)

Fig. 4. Scheme (a) and the surface of the corrosion of a semispherical hole (b, c) and the surface of static failure of the pipe material $(d, e)$

very insignificant manifestations of the local corrosion near the through hole.

The use of the optical microanalysis for the geometry analysis of the corrosion defect bottom testifies to the absence of crack-like defects. The view of the through hole and the general condition of templates testify to an insignificant intensity of corrosion processes on the gas pipeline wall. Based on the results of the damage analysis on the pipeline surface, a conclusion can be made that the through hole with the maximum diameter on the internal wall and the minimum diameter on the external wall is a corrosion pit, which propagated from the inside (Fig. 4a). The shape and locality of the defect allow presuming the presence of a technological defect of the pipe within this area (most probably a film or flanging).

According to literature (Chernov et al. 2002a, $2002 \mathrm{~b}$ ), the sources of corrosion defects of this type are deviations from the process mode during casting and rolling of the pipe metal. This preconditions the chemical and mechanical non-uniformity of the near-surface lay- er of the metal; moreover, such deviations are the local zones of extra-high corrosion activity.

The analysis of the hole surface morphology allowed establishing that the material has a surface fragmented with corrosion, on which flanges covered with the corrosion film are formed (Fig. 4b, c).

It should be noted that the mechanism of steel failure depends on many factors (strength, structural degradation, the presence of concentrators). Failure of the material near the hole occurred in a ductile manner. A dimple relief testifies to the presence of non-metallic inclusions. We can presume that the dimples with the diameter above $10 \mu \mathrm{m}$ are caused by the presence of the non-metallic inclusions of oxides and sulfides, whereas the pits of smaller size are connected with the intrasubgranular mechanism of failure or the formation of pores on dispersed particles (Fig. 4d, e). The attainment of the critical volume of pores caused a beginning of microplastic deformation, coalescence of pores and fast failure. 
Oil pipeline "Gnidyntsi-Glynsko-Rozbyshivska", length $-213 \mathrm{~km}$

A tongue-like defect was found on the pipe surface, which is joined with the base metal of the pipe on one side. These are the so-called films - metallurgical defects caused by violations of the pipe production technology. Films of the steelmaking origin are located randomly along the surface of the metal sheet and have a significant thickness of local delamination (above $1.0 \mathrm{~mm}$ ), and the size up to $35 \mathrm{~mm}$, which is similar to the case under investigation.

The results of determining the chemical composition of a fragment of the oil pipeline are presented in Table 4.

The use of the complex technique for investigating the defects of "film" type (Fig. 5a) and the analysis of pipe production technology allows identifying the reasons for the formation of this type of damage on the walls of the main oil pipeline systems. The external view of the defect of "film"-type represents thin, tongue-like delamination of metal plates from the pipe surface of the oil pipeline (Fig. 5a). The delamination has a shiny dark colour.

The defect was found to have a structural gradient along the depth of fracture (Fig. 5b). In particular, longitudinal delamination of different sizes was noticeable very well. The defects were oriented along the direction of rolling and looked like delamination caused by the effect of hydrogen on the metal (Szklarska-Śmialowska,
Lunarska 1981; Alamilla et al. 2013). This also indicates a significant role of hydrogen in degradation, which is evolved due to the corrosion interaction between the steel and the external medium and which diffuses partly into the metal. Hydrogen can influence the deformation of metal, causing the development of damage, including the nucleation and propagation of submicrocracks. The hydrogen cracking results from the accumulation of atomic hydrogen under significant tensile stresses in the pipeline wall (Szklarska-Śmialowska, Lunarska 1981; Alamilla et al. 2013; Azevedo 2007; Cao et al. 2010).

The structure of the fracture is formed by the lateral shear mechanism (Fig. 5c, d). In general, the surface has a "smoothed-out" look, and a decreased roughness, which testifies to a low energy efficiency of the material fracture.

The analysis of damage of oil and gas pipelines indicates that more than a half of their failures are caused by the action of the corrosion factor. As a rule, such failures are connected with the combined effect of the soil ground and in-service loading. On the other hand, some corrosion damage was also found on the internal surface of the pipe, which testifies to the importance of the problem of corrosion aggressiveness manifested by transported medium components. Therefore, the investigations into the corrosion of the internal surfaces of the main gas pipelines are topical, taking into account the risk of their corrosive or corrosive-mechanical failure (Doglione, Firrao 1998).

Table 4. Chemical composition of a pipe of the gas pipeline Gnidyntsi-Glynsko-Rozbyshivska (Steel 20)

\begin{tabular}{ccccccccccc}
\hline $\mathrm{Fe}$ & $\mathrm{C}$ & $\mathrm{Si}$ & $\mathrm{Mn}$ & $\mathrm{Cr}$ & $\mathrm{Mo}$ & $\mathrm{Ni}$ & $\mathrm{Al}$ & $\mathrm{Cu}$ & $\mathrm{Nb}$ & $\mathrm{W}$ \\
\hline 98.9 & 0.191 & 0.255 & 0.524 & 0.0101 & 0.0048 & 0.0152 & 0.0141 & 0.0244 & 0.0085 & 0.022 \\
\hline
\end{tabular}

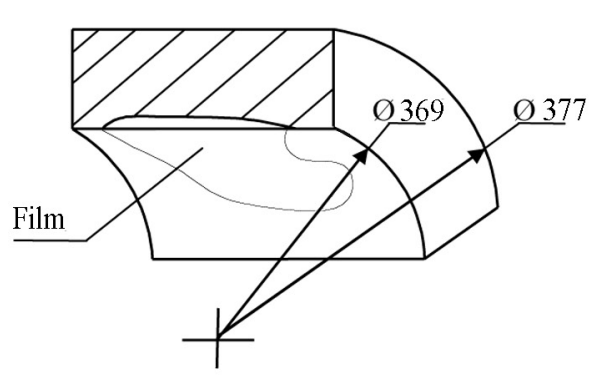

a)

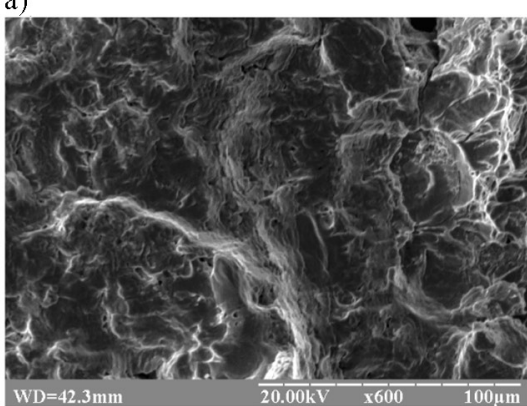

c)

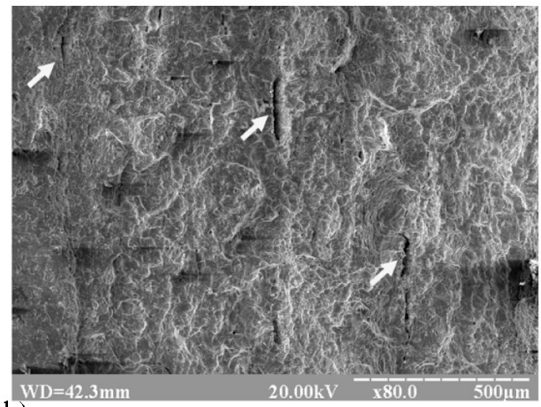

b)

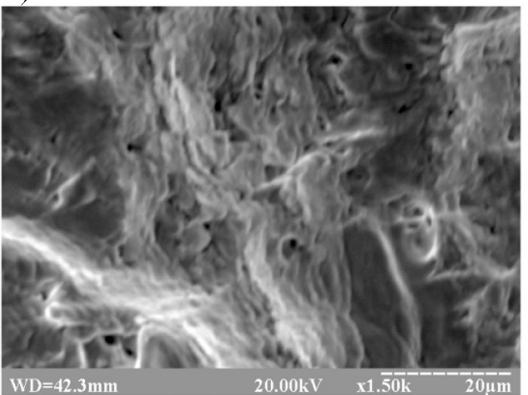

d)

Fig. 5. Film fracture surface (a) and micromechanisms of its fracture (b, c) (hydrogen delamination is indicated by arrows) 


\section{Conclusions}

The main reasons for the formation of the in-service defects in the main oil and gas pipelines are established based on the methods of fractodiagnostics, and the mechanisms of degradation, and failure of their materials are described. Based on the investigation results, it is established that a decreased reliability of the main gas and oil pipeline networks operated for a long time is caused by the general and localised corrosion, as well as technological defects of the pipeline metal.

An important role of the absorbed hydrogen in the processes of the in-service degradation is established. Based on the fractographic control data, it is proved that an intensive trapping of hydrogen takes place in the service-exposed steel, the energy of its binding in traps increases, which causes the defectiveness of the service-exposed metal and the formation of the local micropores and splitting. The decrease of the structural strength of oil and gas pipelines is due to reduction of the cross section, caused by corrosion; softening because of stress relaxation; formation of defects, such as micro cracks; and fragility influenced by hydrogen action.

The exploitation defects of pipelines are systematised and presented in the current paper. This will re-create geometrical characteristics of the oil and gas pipeline in the simulation of stress-strain state by the finite element method.

\section{References}

Alamilla, J. L.; Sosa, E.; Sánchez-Magaña, C. A.; AndradeValencia, R.; Contreras, A. 2013. Failure analysis and mechanical performance of an oil pipeline, Materials \& Design 50: 766-773.

http://dx.doi.org/10.1016/j.matdes.2013.03.055

Aleksandrov, Y. V.; Kuzbozhev, A. S.; Aginej, R. V. 2011. Resursnye ispytaniya metalla dlitel'no jekspluatiruemyh truboprovodov: monografiya. Sankt-Peterburg: Nedra. 304 p. (in Russian).

Azevedo, C. R. F. 2007. Failure analysis of a crude oil pipeline, Engineering Failure Analysis 14(6): 978-994. http://dx.doi.org/10.1016/j.engfailanal.2006.12.001

Cao, Y. G.; Shi, Y. J.; Zhang, S. H.; Xue, S. F.; Sun, X. Y. 2010. Research on strength degradation of oil transmission pipeline by third-party damages, Engineering Failure Analysis 17(4): 992-1007. http://dx.doi.org/10.1016/j.engfailanal.2009.12.002

Chausov, M.; Maruschak, P.; Prentkovskis, O.; Pylypenko, A.; Berezin, V.; Volyanska, K. 2015. Self-organisation of the heat resistant steel structure following dynamic non-equilibrium processes, Solid State Phenomena 220-221: 917-921.

http://dx.doi.org/10.4028/www.scientific.net/SSP.220-221.917

Chernov, V. Y.; Makarenko, V. D.; Kryzhanivs'kyi, E. I.; Shlapak, L. S. 2002a. Causes and mechanisms of local corrosion in oil-field pipelines, Materials Science 38(5): 729-737. http://dx.doi.org/10.1023/A:1024274726352

Chernov, V. Y.; Makarenko, V. D.; Kryzhanivs'kyi, E. I.; Shlapak, L. S. 2002b. On the causes of corrosion fracture of industrial pipelines, Materials Science 38(5): 880-883. http://dx.doi.org/10.1023/A:1024224204487

Doglione, R.; Firrao, D. 1998. Structural collapse calculations of old pipelines, International Journal of Fatigue 20(2): 161168. http://dx.doi.org/10.1016/S0142-1123(97)00100-X
Konovalenko, I. V.; Marushchak, P. O.; Bishchak, R. T. 2014. Automated estimation of damage to the surface of gas main by corrosion pittings, Materials Science 49(4): 493500. http://dx.doi.org/10.1007/s11003-014-9641-7

Liu, Y.; Hu, H.; Zhang, D. 2014. A rule based fuzzy synthetic evaluation method for risk assessment in pipeline transport, Transport 29(4): 355-362. http://dx.doi.org/10.3846/16484142.2014.981858

Maruschak, P.; Poberezhny, L.; Pyrig, T. 2013. Fatigue and brittle fracture of carbon steel of gas and oil pipelines, Transport 28(3): 270-275. http://dx.doi.org/10.3846/16484142.2013.829782

Maruschak, P.; Bishchak, R.; Konovalenko, I.; Menou A.; Brezinová, Z. 2014a. Effect of long term operation on degradation of material of main gas pipelines, Materials Science Forum 782: 279-283.

http://dx.doi.org/10.4028/www.scientific.net/MSF.782.279

Maruschak, P.; Bishchak, R.; Panin, S.; Pylypenko, A.; Menou, A.; Danyliuk, I. 2014b. Influence of in-service degradation on strain localization in steel of main gas pipelines, in AIP Conference Proceedings 1623: 399-402. http://dx.doi.org/10.1063/1.4898966

Maruschak, P.; Danyliuk, I.; Prentkovskis, O.; Bishchak, R.; Pylypenko, A.; Sorochak, A. 2014c. Degradation of the main gas pipeline material and mechanisms of its fracture, Journal of Civil Engineering and Management 20(6): 864-872. http://dx.doi.org/10.3846/13923730.2014.971128

Marushchak, P. O.; Salo, U. V.; Bishchak, R. T.; Poberezhnyi, L. Ya. 2014d. Study of main gas pipeline steel strain hardening after prolonged operation, Chemical and Petroleum Engineering 50(1-2): 58-61. http://dx.doi.org/10.1007/s10556-014-9855-4

Maruschak, P.; Konovalenko, I.; Prentkovskis, O.; Chausov, M.; Pylypenko, A. 2016a. Methods and some results of automated analysis of ductile failure mechanisms of titanium alloy VT-22, Procedia Engineering 134: 475-480. http://dx.doi.org/10.1016/j.proeng.2016.01.070

Maruschak, P.; Konovalenko, I.; Prentkovskis, O.; Tsyrulnyk, O. 2016b. Digital analysis of shape and size of dimples of ductile tearing on fracture surface of long-operated steel, Procedia Engineering 134: 437-442.

http://dx.doi.org/10.1016/j.proeng.2016.01.052

Maruschak, P.; Panin, S.; Vlasov, I.; Prentkovskis, O.; Danyliuk, I. 2015. Structural levels of the nucleation and growth of fatigue crack in $17 \mathrm{Mn} 1 \mathrm{Si}$ steel pipeline after long-term service, Transport 30(1): 15-23. http://dx.doi.org/10.3846/16484142.2014.1003404

Nykyforchyn, H.; Lunarska, E.; Tsyrulnyk, O.; Nikiforov, K.; Gabetta, G. 2009a. Effect of the long-term service of the gas pipeline on the properties of the ferrite-pearlite steel, Materials and Corrosion 60(9): 716-725.

http://dx.doi.org/10.1016/10.1002/maco.200805158

Nykyforchyn, H.; Lunarska, E.; Tsyrulnyk, O.; Nikiforov, K.; Hredil, M. 2009b. In service degradation of mechanical and corrosion-mechanical properties of transit gas pipeline steels, in Mechanika-2009: Proceedings of the 14th International Conference, 2-3 April 2009, Kaunas, Lithuania, 278-283.

Nykyforchyn, H.; Lunarska, E.; Tsyrulnyk, O. T.; Nikiforov, K.; Genarro, M. E.; Gabetta, G. 2010. Environmentally assisted "in-bulk" steel degradation of long term service gas trunkline, Engineering Failure Analysis 17(3): 624-632. http://dx.doi.org/10.1016/j.engfailanal.2009.04.007

Okipnyi, I.; Maruschak, P.; Prentkovskis, O. 2015. Structural hierarchical mechanism for cracking reactor steel after preliminary thermomechanical loading, Solid State Phenomena 220-221: 720-724.

http://dx.doi.org/10.4028/www.scientific.net/SSP.220-221.720 
Slobodyan, Z. V.; Nykyforchyn, H. M.; Petrushchak, O. I. 2002. Corrosion resistance of pipe steel in oil-water media, Materials Science 38(3): 424-429. http://dx.doi.org/10.1023/A:1021738103745

Szklarska-Śmialowska, Z.; Lunarska, E. 1981. The effect of sulphide inclusions on the susceptibility of steels to pitting, stress corrosion cracking and hydrogen embrittlement, Materials and Corrosion 32(11): 478-485. http://dx.doi.org/10.1002/maco.19810321103

Tsyrul'nyk, O. T.; Nykyforchyn, H. M.; Petryna, D. Yu.; Hredil', M. I.; Dz'oba, I. M. 2007. Hydrogen degrada- tion of steels in gas mains after long periods of operation, Materials Science 43(5): 708-717.

http://dx.doi.org/10.1007/s11003-008-9010-5

Voropai, N. I.; Senderov, S. M.; Edelev, A. V. 2012. Detection of "bottlenecks" and ways to overcome emergency situations in gas transportation networks on the example of the European gas pipeline network, Energy 42(1): 3-9. http://dx.doi.org/10.1016/j.energy.2011.07.038

Yemelin, V. 2011. Designing universal drives for trenchless repair of pipelines, Transport 26(1): 69-74. http://dx.doi.org/10.3846/16484142.2011.563493

Pavlo MARUSCHAK. Doctor, Professor at the Department of Industrial Automation, Ternopil National Ivan Pul'uj Technical University, Ukraine. Research interests: transport engineering, pipeline transport, industrial transport, sea and air transport.

Olegas PRENTKOVSKIS. Doctor, Professor at the Department of Transport Technological Equipment, Vilnius Gediminas Technical University, Lithuania. Research interests: vehicles dynamics, simulation of traffic accidents, traffic safety problems, transport infrastructure, numerical methods, pipeline transport.

Roman BISHCHAK. Doctor, Assistant Professor at the Department of Welding of Main Pipelines, Ivano-Frankivsk National Technical University of Oil and Gas, Ukraine. Research interests: fatigue, fracture mechanics, welding, oil pipelines, pipeline operation, protection, inspection and maintenance. 